\title{
TINJAUAN PELAKSANAAN PEMUTUSAN HUBUNGAN KERJA (PHK) BERDASARKAN UNDANG-UNDANG NOMOR 13 TAHUN 2003 TENTANG KETENAGAKERJAAN
}

\begin{abstract}
Widayanti *
ABSTRACT

Termination of Employment Relations based on the Law No.13 of 2003 is considered necessary because it often leads to discontent for workers / laborers as has not fulfilled the right of the right workers / labor as it should. It causes the workers to fret when the worker becomes the backbone of the family, the worker / laborer has the responsibility to sustain his economic life, for it needs the protection of workers in the right that should be obtained and how to solve it. From the results of the discussion, some rights were obtained, among others, replacement money, severance pay, and term of employment and settlement of Termination of Employment including Bipartite, Mediation, Conciliation, Arbitase.
\end{abstract}

Keywords : Termination of Employment, Workers/laborers

\section{PENDAHULUAN}

Pemutusan Hubungan Kerja (PHK) selalu menarik untuk dikaji dan ditelah lebih mendalam pasalnya fakta menunjuk kan bahwa Pemutusan Hubungan Kerja (PHK) seringkali menimbulkan ketidak puasan bagi salah satu pihak dikarenakan masing-masing pihak memiliki sudut pandang yang berbeda dalam menyikapi Pemutusan Hubungan Kerja (PHK). Pengusaha menganggap Pemutusan Hubungan Kerja (PHK) merupakan hal yang wajar di dalam kegiatan perusahaan, sedangkan bagi pekerja/buruh menganggap bahwa Pemutusan Hubungan Kerja (PHK) akan berdampak luas bagi kehidupannya tidak hanya bagi dirinya pribadi namun juga keluarganya. Pemutusan Hubungan Kerja (PHK) jelas akan menyebabkan seorang pekerja/buruh akan kehilangan mata pencahariannya. Dalam lingkup yang lebih luas, keluarga akan tergantung pada pekerja/buruh sebagai tulang punggung keluarga dan kesulitan dalam memenuhi

* Widayanti, Dosen Fakutas Hukum Universitas 17 Agustus 1945 Semarang dapat dihubugi melalui email :maulidamdp17@gmail.com kebutuhan sehari-hari termasuk biaya sekolah anak-anak mereka. ${ }^{1}$

Pemutusan Hubungan Kerja (PHK) yang berakhir karena waktu yang telah ditetapkan dalam perjanjian kerja tidak menimbulkan permasalahan terhadap kedua belah pihak namun jika pemutusan kerja berakhir karena adanya perselisihan dapat menyebabkan polemik antara kedua belah pihak.Menurut Undang-undang No. 13 Tahun 2003 mengartikan bahwa Pemutusan Hubungan Kerja merupakan pengakhiran hubungan kerja karena suatu hal tertentu yang mengakibatkan berakhir nya hak dan kewajiban antar pekerja dengan pengusaha. Namun UndangUndang yang mengatur mengenai PHK tersebut memiliki kelemahan. Karena law inforcement yang terdapat dilapangan juga masih rendah, sehingga infrastruktur penegakan hukum tidak mampu untuk melaksanakan apa yang sudah diatur dalam undang-undang. ${ }^{2}$

1 Utami, T. K. (2013). Peran Serikat Pekerja dalam Penyelesaian Perselisihan Pemutusan Hubungan Kerja. Wawasan Hukum, 676-686.

2 Republik Indonesia. Undang - undang Nomor 13 Tahun 2003 Tentang Ketenagakerjaan 
Banyak pihak yang salah dalam menafsirkan alasan-alasan melakukan PHK terutama ketentuan Pasal 164ayat (3) Undang - Undang No 13 Tahun 2003 tentang ketenagakerjaan bahwa pengusaha dapat melakukan Pemutusan Hubungan Kerja (PHK) terhadap pekerja/buruh karena perusahaan tutup bukan karena perusahaan mengalami kerugian selama 2 tahun berturut-turut atau karena keadaan terpaksa, tetapi perusahaan melakukan efisiensi dengan ketentuan hak atas uang pesangon sebesar 2 kali ketentuan pasal 156 ayat (2), uang penghargaan masa kerja sebesar 1 kali lipat sesuai ketentuan pasal 156 ayat (3) dan uang pengganti sesuai ketentuan pasal 156 ayat (4)

Dampak dari Pemutusan Hubungan Kerja (PHK) sangat kompleks dan cenderung menimbulkan perselisihan pasalnya ketika pekerja/ buruh mengalami PHK karena perselisihan maka penganggur an akan meningkat, dan seiring bertambah nya jumlah penduduk dan ketika lapangan pekerja yang tersedia tidak memadai maka tingkat kriminalitas akan tinggi pula, untuk itu diperlukan mekanisme prosedur PHK yang diatur sedemikian rupa agar pekerja/buruh telah mendapatkan per lindungan yang layak dan memperoleh hak hak sesuai dengan ketentuan. Maksud dan tujuan perlindungan buruh atau per lindungan pekerja adalah agar pekerja dapat dilindungi dari perlakuan pemerasan dari pihak pengusaha.

Berdasarkan permasalahan diatas maka penulis menulis jurnal dengan judul tinjauan pelaksanaan pemutusan hubungan kerja (PHK) berdasarkan Undang-Undang No. 13 Tahun 2003 tentang ketenaga kerjaan, dan untuk memudahkan penulis dalam menganalisa permasalahan tersebut maka penulis merumuskan masalah sebagai berikut:

1. Bagaimana hak-hak pekerja/buruh apabila terjadi Pemutusan Hubungan Kerja (PHK)?

2. Bagaimana langkah-langkah penyelesaian perselisihan apabila terjadi Pemutusan Hubungan Kerja (PHK)?

\section{PEMBAHASAN}

\section{Hak hak pekerja/ buruh apabila terjadi Pemutusan Hubungan Kerja (PHK)}

Tidak semua pekerja/buruh takut akan Pemutusan Hubungan Kerja (PHK), PHK bisa terjadi ketika pensiun kontrak perjanjian yang telah berakhir sesuai kesepakatan oleh kedua pihak, dan karena pekerja/buruh yang mengundurkan diri. untuk itu penulis ingin memperjelas kembali terkait dengan jenis-jenis Pemutusan Hubungan kerja beserta hak hak yang didapat oleh pekerja/buruh.

Jenis-jenis Pemutusan Hubungan Kerja (PHK) yaitu sebagai berikut:

a. PHK oleh majikan /pengusaha, yaitu PHK oleh pihak pengusaha terjadi karena keinginan dari pihak pengusaha dengan alasan persyaratan, dan prosedur tertentu.

b. PHK oleh pekerja/buruh, yaitu PHK oleh pihak pekerja terjadi karena keinginan dari pihak pekerja dengan alasan tertenttu dan prosedur tertentu.

c. PHK demi hukum, yaitu PHK yang terjadi tanpa perlu adanya suatu tindakan, terjadi dengan sendirinya misalnya karena berakhirnya waktu atau karea meninggalnya pekerja.

d. PHK oleh pengadilan (PPHI), yaitu PHK oleh putusan pengadilan terjadi karena alasan-alasan tertentu yang mendesak dan penting, misalnya terjadinya peralihan kepemilikan, peralihan asset atau pailit. ${ }^{3}$

Dalam Undang-Undang No. 13 Tahun 2003 tentang ketenagakerjaan telah diatur jenis-jenis pemutusan hubungan kerja, sebagai berikut:

a. PHK Kerja karena kesalahan berat

3 Adrian Sutedi, S. (2011). Hukum Pemburuhan. Jakarta: Sinar Grafika. 
b. PHK karena Pekerja/buruh ditahan

c. PHK karena Pekerja/buruh Melanggar perjanjian kerja

d. PHK karena mengundurkan diri

e. PHK karena perubahan Status, Merger, Konsolidasi, atau Akuisisi Perusahaan

f. PHK karena Likuidasi Perusahaan

g. PHK karena Pailit

h. PHK karena pekerja/buruh meninggal dunia

i. PHK karena pekerja/buruh pensiun

j. PHK karena pekerja/buruh mangkir

k. PHK karena permohonan pekerja/ buruh

1. PHK karena sakit dan/atau cacat total tetap

\section{Hak-hak pekerja atau buruh apabila terjadi PHK}

Sebelumnya sudah dijelaskan bahwa Pemutusan Hubungan Kerja dapat terjadi karena berbagai alasan dan tidak semua PHK menjadi hal yang sangat ditakuti oleh pekerja, berikut merupakan hak hak pekerja berdasarkan jenis Pemutusan Hubungan Kerja UndangUndang No.13 Tahun 2003 tentang ketenagakerjaan sebagai berikut:

a. Hak karena Pekerja/buruh yang di PHK karena kesalahan berat

Pekerja/buruh yang di PHK karena kesalahan berat dapat memperoleh uang pengganti sesuai pasal 156 ayat (4). Bagi Pekerja/buruh yang tugas dan fungsinya tidak mewakili kepentingan pengusaha secara langsung,selain mendapat uang pengganti hak, diberikan uang pisah yang sebesar dan pelaksanaannya/ perjanjian kerjasama

Pekerja/buruh yang tugas dan fungsinya mewakili kepentingan pengusaha adalah pekerja/ buruh yang karena jabatannya menduduki jabatan tertentu sebagaimana ditentukan dalam PP/PKB. Jabatan-jabatan tertentu tersebut, dapat ditentukan satu per satu berdasarkan kepentingan (manajemen) perusahaan atau ditentukan level tertentu secara menyeluruh ke atas.

Sebagaimana disebutkan, PHK kesalahan berat adalah salah satu jenis PHK yang tidak memerlukan izin dari lembaga PPHI (pasal 171jo. Pasal 158 ayat (1)). Dalam hal terjadi pemutusan hubungan kerja karena pekerja/buruh melakukan kesalahan berat dan pekerja/buruh tidak menerima PHK tersebut,pekerja/buruh yang bersangkutan dapat mengajukan gugatan ke lembaga PPHI atas PHK dimaksud (pasal 159)

b. Hak Pekerja/buruh yang ditahan atau selanjutnya di PHK

Dalam hal pekerja/buruh ditahan pihak yang berwajib karena diduga melakukan kesalahan tindak pidana (bukan atas pengaduan pengusaha) maka pengusaha tidak wajib membayar upah, tetapi wajib memberikan bantuan kepada keluarga pekerja/buruh yang bersangkutan yang menjadi tanggungannya sebagai berikut:

1) 1 orang, $25 \% \times$ upah

2) 2 orang, $35 \% \times$ upah

3) 3 orang, $45 \% \times$ upah

4) 4 orang/lebih, $50 \% \times$ upah (pasal 160 ayat(1)

Bantuan tersebut hanya diberikan paling lama enam bulan takwin terhitung sejak hari pertama ditahan oleh pihak yang berwajib (pasal 160 ayat(2)), selain pengusaha memberikan bantuan kepada keluarga pekerja/buruh, apabila pekerja/ buruh di PHK, pengusaha wajib membayar hak-hak pekerja/buruh yang di PHK karena alasan ditahan pihak yang berwajib tersebut, yakni penghargaan masa kerja (satu kali ketentuan pasal 156 ayat(3)) dan uang pengganti hak (sesuai ketentuan pasal 156 ayat (4)).

c. Hak Pekerja/buruh melanggar perjanjian kerja (PK) Peraturan Perusahaan (PP), atau Perjanjian Kerja Bersama (PKB)

Pekerja/buruh yang diputuskan 
hubungan kerjanya karena melakukan pelanggaran dalam $\mathrm{PK}$ dan $\mathrm{PP} / \mathrm{PKB}$ memperoleh hak atas pesangon uang penghargaan masa kerja masing- masaing satu kali, uang pesangon dan uang pengganti sesuai ketentuan.

d. Hak Pekerja/buruh yang di PHK karena Mengundurkan Diri

Apabila pekerja/buruh mengundur kan diri atas kemauan sendiri yang tugas dan fungsinya tidak mewakili kepentingan pengusaha secara langsung, haknya adalah uang pengganti dan hak uang pisah. Besar dan jumlah UPH sebagaimana ditentukan dalam pasal 156 atay (4). Adapun besarnya uang pisah tersebut dan pengaturan pelaksanaan (pemberi)nya diatur dalam PK atau PP/PKB

e. Hak Pekerja/buruh yang di PHK karena Perubahan status, Merger, Konsolidasi, atau Akuisisi Perusahaan

Dalam hal terjadi PHK karena perubahan status, merger, konsolidasi, dan akuisisi dan pekerja/buruh tidak bersedia melanjutkan hubungan kerja maka terhadap pekerja/buruh berhak atas uang pesangon satu kali dan uang pengganti hak. Apabila PHK yang terjadi disebabkan oleh perubahan status, merger, atau konsolidasi dan perusahaan tidak bersedia melanjutkan hubungan kerja dengan pekerja/buruh maka pekerja berhak mendapatkan uang pesangon dua kali,uang penghargaan masa kerja satu kali, dan uang pengganti hak.

f. Hak Pekerja/buruh yang di PHK karena

Likuidasi Perusahaan

Apabila perusahaan tutup karena merugi atau karena forcemajeur maka pekerja/buruh berhak atas uang pesangon, uang penghargaan masa kerja masing masing satu kali ketentuan, dan uang pengganti hak. Namun apabila perusahaan tutup bukan karena merugi atau bangkrut maka pekerja/buruh berhak atas uang pesangon dua kali, uang penghargaan masa kerja satu kali ketentuan, dan uang pengganti hak.

g. Hak Pekerja/buruh karena Perusahaan
Pailit

Pekerja/buruh yang di PHK karena kepailitan berhak atas uang pesangon satu kali, uang penghargaan masa kerja satu kali, dan uang pengganti hak.

h. Hak Pkerja/buruh karena Pekerja/ buruh Meninggal Dunia

Apabila pekerja/buruh meninggal, kepada ahli warisnya diberikan "sejumlah uang" yang besarnya sama dengan perhitungan 2 kali pesangon, satu kali uang penghargaan masa kerja dan uang pengganti hak.

i. Hak Pekerja/buruh karena Pekerja/ buruh Pensiun

Apabila pekerja/buruh diputuskan hubungan kerja karena memasuki usia pensiun yang telah ditentukan dan pekerjaan/buruh yang bersangkutan tidak ikut/diikutkan dalam program pensiun maka pengusaha wajib memberikan uang pesangon dua kali, uang penghargaan masa kerja, dan satu kali uang penganti hak.

j. Hak Pekerja/buruh karena Pekerja/ buruh Mangkir

Hak atas pekerja/buruh yang mangkir mendapatkan uang penggantian dan diberikan uang pisah. Disini pemberian uang pisah tidak disyaratkan harus terhadap pekerja/buruh yang tugas dan fungsinya tidak mewakili kepentingan pengusaha secara langsung. Dengan demikian siapa saja pekerja/buruh yang mangkir dan memenuhi syarat, berhak untuk mendapat kan yang pisah yang tidak lagi dipersyarat kan harus pada jabatan yang tugas dan fungsinya tidak mewakili kepentingan pengusaha secara langsung.

f. Hak Pekerja/buruh yang di PHK karena Permohonan dari Pekerja/buruh

Apabila permohonan pekerja/buruh yang bersangkutan dikabulkan oleh lembaga PPHI dan kemudian di PHK maka pekerja/buruh yang masa kerja satu kali,uang penggantian hak. Dalam hal pengusaha ternyata tidak terbukti melakukan perbuatan yang dituduhkan maka pekerja/buruh dapat di PHK tanpa 
penetapan dan tanpa hak atas uang pesangon dan uang penghargaan kerja. Dalam hal penggantian hak, namun tersirat bahwa pekerja/buruh tetap berhak atas uang penggantian hak tersebut.

g. Hak Pekerja/buruh yang di PHK karena Sakit/Cacat Total

Hak pekerja/buruh yang di PHK karena sakit berkepanjangan akibat kecelakaan kerja adalah uang pesangon dua kali, uang penghargaan masa kerja dua kali, dan uang pengganti hak.

Demikian jenis Pemutusan Hubungan Kerja dan hak-hak pekerja/ buruh apabila terjadi PHK, apabila Pemutusan hubungan kerja yang ketentuan dan alasan pemutusannya serta hak-haknya tidak diatur dalam undang-undang sebagaimana telah dikemukakan bahwa hubungan kerja merupakan salah satu hubungan hukum yang timbul atau lahir karena perjanjian,yakni perjanjian kerja (perjanjian perburuhan). Dengan adanya perjanjian tersebut, lahir perikatan yaitu perikatan dalam hubungan yang mewajibkan kepada pihak untuk menunaikan kewajiban dan menuntut haknya masing-masing.

Sebagaimana diketahui, bahwa ikatan kerja ada karena perjanjian, dan karena Undang-undang (Pasal $1234 \mathrm{KUH}$ Perdata). Oleh karena itu, kalau perikatan tersebut tidak diatur dalam Undangundang, selayaknya diatur dan diperjanji kan oleh kedua belah pihak. Dengan kata lain, apa yang diatur dalam Undang-undang adalah ikatan yang ada karena Undangundang. Dengan demikian, apabila Undang-undang tidak megaturnya atau Undang-undang tidak melahirkan suatu kewajiban, tentunya harus diartikan melalui perjanjian yang akan melahirkan kewajiban yang mungkin saling bertimbal balik.

\section{Langkah -langkah yang ditempuh oleh pekerja/buruh apabila terjadi Pemutusan Hubungan Keja (PHK)}

Prodesur dari PHK sendiri,berikut merupakan prosedur PHK menurut UU No.13 Tahun 2003 ialah:

a. Sebelumnya semua pihak harus melakukan upaya untuk menghindari terjadinya PHK

b. Bila tidak dapat dihindari, pengusaha dan serikat pekerja mengadakan perundingan

c. Jika perundingan berhasil, buat persetujuan bersama

d. Bila tidak berhasil, pengusaha mengaju kan permohonan penetapan disertai dasar dan alasan-alasannya kepada lembaga penyelesaian perselisihan hubungan industrial

e. Selama belum ada penetapan/putusan dari lembaga penyelesaian perselisihan hubungan industrial, kedua pihak teteap melaksanakan segala kewajiban masing-masing.

Perselisihan di hubungan industri dibagi menjadi 4 berdasarkan UndangUndang Dasar (UUD) No. 2 Tahun 2004 tentang penyelesaian perselisihan hubungan yaitu:

a. Perselisihan hak ialah perselisihan yang timbul karena tidak dipenuhi hak, akibat adanya perbedaan pelaksanaan atau penafsiran tehadap ketentuan peraturan perundang-undangan, perjanjian kerja, peraturan perusahaan atau perjanjian kerja bersama

b. Perselisihan kepentingan, ialah perselisihan yang timbul dalam hubungan kerja karena tidak adanya kesesuaian pendapat mengenai pembuatan dan atau perubahan syaratsyarat kerja yang ditetapkan dalam perjanjian kerja, atau peraturan perusahaan atau perjanjian kerja bersama

c. Perselisihan pemutusahan hubungan kerja adalah perselisihan yang timbul karena tidak adanya kesesuaian pendapat mengenai pengakhiran hubungan kerja yang dilakukan oleh salah satu pihak 
d. Perselisihan antar serikat pekerja / serikat buruh adalah perselisihan antara serikat pekerja / serikat buruh dengan serikat pekera / serikat buruh lain hanya dalam satu perusahaan karena tidak adanya persesuaian paham mengenai keanggotaan, pelaksanaan hak dan kewajiban keserikatan pekerjaan. ${ }^{4}$

\section{Pengertian peselisihan}

Perselisihan hak adalah perselisihan yang timbul karena tidak dipenuhi hak, akibat adanya perbedaan pendapat tentang pelaksanaan atau penafsiran terhadap ketentuan-ketentuan yang telah diatur dalam peraturan perundang-undangan, perjanjian kerja, peraturan perrusahaan, atau perjanjian kerja bersama perselisihan hak sering disebut juga sebagai perselisihan normatif, yaitu perselisihan terhadap permasalahan yang sudah ada pengaturan nya atau dasar hukumnya. ${ }^{5}$

Di dalam UU No. 2 Tahun 2004, tata cara penyelesaian hubungan industrial sebagai berikut:

a. Penyelesaian melalui Bipartit

Sebelum perselisihan diajukan kepada lembaga penyelesaian perselisihan, setiap perselisihan wajib diupayakan perselisihan bipartite yaitu musyawarah antara pekerja dengan pengusaha. Bipartit bersifat mengikat. Dengan paling lama penyelesaian 30 hari kerja sejak dimulainya perundingan. ${ }^{6}$

Apabila dalam perundingan Birpatit berhasil mencapai kesepakatan maka dibuat perjanjian bersama (PB) yang mengikat dan menjadi hukum serta wajib dilaksanakan oleh para pihak Sedangkan apabila perundingan Bipartit tidak mencapai kesepakatan, salah satu atau

4 Republik Indonesia. Undang- Undang Nomor 2 Tahun 2004 tentang tata cara penyelesaian hubungan industrial

5 Prabowo, H. (2011). Implementasi Hak Pekerja dalam Penyelesaian Perselisihan Hubungan Inndustrial. Semarang.

6 Nasutions Sanwani, S. Arbitase dalam Hukum Internasional. Fakultas Hukum USU Medan. kedua belah pihak memberitahukan perselisihannya kepada instansi yang bertanggung jawab di bidang ketenaga kerjaan setempat.

b. Penyelesaian melalui Mediasi

Penyelesaian melalui hubungan industrial (mediasi) adalah penyelesaian perselesihan hubungan industrial melalui musyawarah yang ditengahi oleh seorang atau lebih mediator yang netral.

Mediator adalah pegawai intansi pemerintah yang bertanggung jawab di bidang ketenagakerjaan yang memenuhi syarat- syarat sebagai mediator yang ditetapkan oleh menteri untuk bertugas melakukan mediasi dan mempunyai kewajiban memberikan anjuran tertulis kapada pihak yang berselisih.

Dalam waktu selambat - lambatnya tujuh hari kerja setelah menerima permintaan tertulis, mediator harus sudah mengadakan penelitian tentang duduknya perkara dan segera mengadakan siding mediasi.

Dalam hal tercapai kesepakatan penyelesaian melalui Mediasi, dibuat perjanjian bersama (PB) yang ditanda tangani para pihak dan diketahui oleh mediator dan didaftar di pengadilan hubungan industrial pada oengadilan negeri di wilayah pihak-pihak mengadakan perjanjian bersama.

Dalam hal mediasi tidak mencapai kesepakatan, mediator menegeluarkan anjuran tertulis selambat - lambatnya 10 hari kerja sejak siding mediasi pertama kepada para pihak.para pihak harus memberikan pendapatnya secara tertulis kepada mediator selambat-lambatnya 10 hari kerja sejak anjuran tertulis.

Dalam hal pihak menyetujui anjuran tertulis dari mediator, dalam waktu selambat- lambatnya tiga hari kerja sejak anjuran tertulis disetujui, mediator harus sudah selesai membantu para pihak membuat perjanjian bersama (PB) untuk kemudian didaftar di Pengadilan Hubungan Industrial pada Pengadilan Negeri di 
wilayah pihak-pihak mengadakan perjanjian bersama $(\mathrm{PB})$

Apabila anjuran tertulis ditolak oleh salah satu pihak atau oleh keuda belah pihak, pneyelesaian perselisihan dilakukan melalui Pengadilan Hubungan Industrial pada Pengadilan Negeri setempat dapat mengajukan gugatan oleh salah satu pihak. Mediator harus menyelesaikan tugasnya paling ama 30 hari kerja sejak tanggal permintaan penyelesaian perselisihan.

c. Penyelesaian Melalui Konsiliasi

Lembaga penyelesaian perselisihan yang berwenang untuk menjadi penengah dalam perselisihan kepentingan, pemutus an hubungan kerja, dan perselisihan antar serikat pekerja. Yang bertugas sebagai penengah adalah konsiliator, yaitu orang yang memenuhi syarat sesuai ketetapan menteri dan wajib memberikan anjuran tertulis kepada para pihak yang berselisih. Perselisihan yang dapat diselesaikan dengan konsoliasi antara lain

1). Perselisihan kepentingan

2). Perselisihan pemutusan hubungan kerja

3). Perselisihan serikat pekerja/serikat buruh

Ketika anjuran tertulis ditolak oleh salah satu pihak atau para pihak, penyelesaian perselisihan dilakukan melaui Pengadilan Hubungan Industrial pada Pengadilan Negeri setempat dengan pengajuan gugatan oleh salah satu pihak.

a. Penyelesaian Melalui Arbitrase

Istilah arbitrase berasal dari kata abitrase (bahasa latin) yang berarti kekuasaan untuk menyelesaiakan sesuatu perkara menurut kebijaksanaan Pengertian arbitase menurut beberapa ahli sebagai berikut:

1). Arbitase adalah penyelesaian atau pemutusan sengketa oleh seorang hakim atau para hakim yang bertujuan mereka untuk tunduk kepada atau mentaati keputusan yang telah diberikan oleh hakim atau para hakim yang mereka pilih atau tunjuk tersebut. ${ }^{7}$
2). Asikin Kusumah Atmaja, menyatakan "bahwa abitrase merupakan suatu prosedur di luar pengadilan yang ditentukan berdasarkan sesuatu perjanjian, dimana para pihak dalam hal timbulnya sengketa mengenai pelaksanaan perjanjian tersebut menyetujui penyerahan perselisihan sengketa tersebut pada wasit yang telah dipilih oleh para pihak itu sendiri.

3). Frank Kaoury dan Edna El Kaoury dalam buku mereka How Arbitration Works, mengatakan bahwa abitrase adalah proses yang mudah atau simple yang dipilih oleh para pihak secara sukarela yang ingin prakaranya diputus oleh juru pisah yang netral sesuai pilihan mereka. $^{9}$

4). Sanwani Nasution, Sulaiman Hamid, dan Bachtiar Hamzah telah mengutip pendapat J.L Bierly yang mengatakan bahwa abitrase adalah suatu proses hukum yan telah ditetapkan dan merupakan satu diantara cara penyelesaian sengketa secara damai. ${ }^{10}$

Menurut Undang- undang No. 22 Tahun 1957 telah memberikan ruang dalam menyelesaikan perselisihan melalui dewan pemisah (abritase), namun kenyataannya dalam kurun waktu 48 tahun undangundang tersebut berjalan, perselisihan yang dielesaikan melalui arbitase dapat dihitung dengan jari, ini membuktikan pihak- pihak yang berselisih ternyata masih enggan menempuh jalur arbitase untuk menyelesai kan perselisihan perburuhan.

Hal ini disebabkan oleh beberapa hal, misalnya masih kurangnya pemahaman tentang arbitase itu sendiri karena belum memasyarakat, kemampuan para arbiter

7 Erman, R. (2000). Abitrsae dan Putusan Pengadilan. Jakarta: Candra Pratama .

8 Asikin, A. K. (1973). Arbitase Perdagangan Internasional. Prisma.

9 M. Hussyen Umar,A. Supriyoni Kardono, Hukum dan Lembaga Arbitase di Indonesia , Proyek Pengembangan Hukum dan Penyempurnaan Sistem Pengadaan, 1995, hlm 2.

10 M, H. U., \& Supriyani, K. (1995). Hukum dan Lembaga Arbitase di Indonesia. 
yang menyelesaikan perselisihan tidak sesuai dengan harapan masyarakat, prosedur penyelesaian tidak jelas atau perangkat peraturannya yang kurang dan lain- lain penyebabnya, berikut merupakan alasan mengapa para pihak menggunakan aribitase ini antara lain:

a. Adanya kebebasan, kepercayaan, dan keamanan dalam penyelesaian perselisihan.

b. Arbiter memiliki keahlian (expertise) untuk memeriksa dan memutus perselisihan dinilai objektif.

c. Penyelesaian lebih cepat dan hemat biaya (arbitration is a simple proceding)

d. Bersifat rahasia

e. Adanya kepekaan arbiter dalam mengambil keputusan

f. Bersifat nonpreseden

g. Pelaksanaan lebih mudah dilaksanakan Berdasarkan empat jenis perselisih an hanya terdapat 2 perselisihan yang dapat diselesaikan melalui arbitase adalah

a. Perselisihan kepentigan

b. Perselisihan antar serikat pekerja / serikat buruh

Terhadap putusan arbitase, dalah satu pihak dapat mengajukan permohonan pembatalan kepada Mahkamah Agung dalam waktu selambat-lambatnya 30 hari kerja sejak ditetapkan putusan arbitase.

\section{KESIMPULAN}

Dari pembahasan diatas didapat kesimpulan sebagai berikut:

1. Pemutusan Hubungan Kerja merupakan pengakhiran hubungan kerja karena suatu hal tertentu yang mengakibatkan berakhirnya hak dan kewajiban antar pekerja dengan pengusaha terdapat beberapa alasan yang menyebabkan pekerja/buruh terkena Pemutusan Hubungan Kerja (PHK) diantaranya:

a. PHK oleh pengusaha yakni pemutusan hubungan kerja yang terjadi disebabkan karena keinginan dari pengusaha

b. PHK oleh pekerja/buruh yakni pemutusan hubungan kerja yang disebabkan karena keinginan dari pekerja/buruh

c. PHK oleh hukum yakni pemutusan hubungan kerja yang disebabkan karena suatu tindakan

d. PHK oleh pengadilan yakni pemutusan hubungan kerja yang disebabkan karena alasan - alasan tertentu yang mendesak

2. Hak- hak yang didapat pekerja/buruh apabila terjadi pemutusan hubungan kerja yaitu uang pengganti hak, uang penghargaan masa kerja, dan uang pesangon. Untuk besarnya biaya tersebut diatur menurut Undangundang yang berlaku. Penyelesaian pemutusan hubungan kerja menurut Undang-undang No. 2 Tahun 2004 antara lain:

a. Penyelesaian melalui Birpatit

b. Penyelesaian melalui Mediasi

c. Penyelesaian melalui konsiliasi

d. Penyelesaian melalui arbitase

\section{SARAN}

Hendaknya dalam melakukan Pemutusan Hubungan Kerja harus sesuai dengan Undnag- Undang yang berlaku di Indonesia agar tidak ada yang merasa dirugikan dan sebaiknya Pemutusan Hubungan Kerja merupakan jalan terakhir dari sebuah persoalan dalam perusahaan.

Sebaiknya dalam menyelesaiakan permasalahan dalam Hubungan Kerja dilakukan secara mufakat yang telah disepakati oleh kedua belah pihak.

\section{DAFTAR PUSTAKA}

Adrian Sutedi, S. (2011). Hukum Pemburuhan. Jakarta: Sinar Grafika.

Asikin, A. K. (1973). Arbitase Perdagangan Internasional. Prisma. 
Widayanti : Tinjauan Pelaksanaan Pemutusan Hubungan Kerja (PHK) berdasarkan .....

Asyhadie, Z. (2007). Hukum Ketenagakerjaan Bidang Hubungan Kerja. Jakarta: PT Raja Grafindo.

Cahyo, N. (2006). Pengalihan Pekerjaan Peunjang Perusahaan dengan Sistem Outsourching (Alih Daya) Menurut Undang- Undang No.13 Tahun 2003 tentang Ketenagakerjaan ((studi kasus Asuransii Astra Buama). Depok: Universitas Indonesia.

Erman, R. (2000). Abitrsae dan Putusan Pengadilan. Jakarta : Candra Pratama .

Erman, R. (2000). Arbitase dan Putusan Pengadilan. Jakarta: Candra Pratama.

Farianto, \& Darmanto. (2009). Himpunan Putusan Mahkamah Agung dalam Perkara PHI tentang Pemutusan Hubungan Kerja (PHK) disertai Ulasan Hukum. Jakarta: PT Raja Grafindo.

Indonesia, R. (n.d.). Undang- undang Nomor 13 Tahun 2003 tentang Ketenagakerjaan.

M, H. U., \& Supriyani, K. (1995). Hukum dan Lembaga Arbitase di Indonesia.

Nasutions Sanwani, S. (n.d.). Arbitase dalam Hukum Internasional. Fakultas Hukum USU Medan.

Prabowo, H. (2011). Implementasi Hak Pekerja dalam Penyelesaian Perselisihan Hubungan Inndustrial. Semarang.
Ramadhon, A. M. (2016). Perlindungan Hukum Terhadap Hak- Hak Pekerja/Buruh yang Terkena PHK Akibat Efisiensi dalam Suatu Perusahaan. Yogyakarta: Universitas Gadjah Mada.

Suwardjo, S. (n.d.). Prosedur Penyelesaian Perselisihan Hubungan Industrial Pancasila. Surakarta: jurnal tidak dipublikasikan.

Utami, T. K. (2013). Peran Serikat Pekerja dalam Penyelesaian Perselisihan Pemutusan Hubungan Kerja. Wawasan Hukum, 676-686.

Vitriani Nala Kirana, S. (2013). Pelaksanaan Pemutusan Hubungan Kerja Karena Renovasi Hotel (studi kasus PHK Hotel Papandayan Bandung). Yogyakarta : Universitas Gadjah Mada.

Zulhartanti, S. (2010). Pengaruh Pemutusan Hubungan Kerja terhadap Karyawan Perusahaan . Pendidikan Sosiologi dan Humaniora, 78-88

Undang- undang Nomor13 Tahun 2003 tentang Ketenagakerjaan. 